\section{Psychosocial, health and demographic characteristics of quality of life among patients with acute myeloid leukemia and malignant lymphoma who underwent autologous hematopoietic stem cell transplantation}

\author{
Second Department of Internal Medicine, Charles University Hospital, \\ Hradec Kralove, Czech Republic
}

INTRDDUCTION

Quality of life (QOL) is defined as patients' subjective evaluation of their life situation. ${ }^{1,2}$ QOL ratings contain information on individuals' physical, psychological, social and spiritual condition. ${ }^{3,4}$ QOL evaluations are carried out by means of generic and specific questionnaires. $^{1-4}$

Hematopoietic stem cell transplantation (HSCT) is a specific therapeutic method used for biomodulatory antitumor therapy on hematological malignancies and solid tumors. It is also used for therapy on non-tumor and hereditary diseases. ${ }^{1}$

HSCT influences the further course of the disease and through this it influences patients' QOL in the same way as do other therapeutic methods. ${ }^{1,2}$

口BJECTIVE

To assess the relationship between patients' characteristics (psychosocial: education level, marital status and religion; health: number of associated diseases, smoking status, type of disease and time elapsed since HSCT; demographics: age and sex) and QOL among patients with acute myeloid leukemia (AML) and malignant Hodgkin's and non-Hodgkin's lymphoma (ML) who were treated with autologous HSCT.

MATERIAL AND METHODS

We carried out this retrospective study among AML and ML patients who had been treated with autologous HSCT between 2001 and 2003. This study was based on data obtained between September 1, 2004, and January 31, 2005. We evaluated the effect of selected psychosocial, health and demographic characteristics of these AML and ML patients on their QOL. The total number of respondents was 36. All respondents were aged over 18 years. This study was approved by Charles University Hospital Ethics Committee.

The evaluation of QOL among these respondents was performed using the Czech version of the international generic European Quality-of-Life questionnaire (EQ-5D). ${ }^{1,2,5}$ This questionnaire evaluates two indicators: one objective and the other subjective. The objective indicator includes five dimensions of QOL: ability to move, self-sufficiency, usual activity, pain/complaints and anxiety/depression. Three responses that express the degree of complaints are offered for each question (no complaints, mild complaints or severe complaints). The outcome from this is the EQ-5D score (QOL dimension), which has values from 0 to 1 ( $0=$ worst health condition; 1 = best health condition). The subjective indicator consists of a visual analog scale $(0=$ worst health condition; $100=$ best health condition). The outcome from this is the EQ-5D visual analog scale (VAS) (subjective health condition), which has values from 0 to 100 . The questionnaires were evaluated by means of descriptive analysis in accordance with the European Quality-of-Life Group methodology. ${ }^{1,2,5}$

The statistical analysis used analysis of variance (ANOVA). Descriptive analysis was used to evaluate the QOL questionnaire. The statistical analysis was conducted using the StatSoft Statistica database, version 7.1. p-values $<0.05$ were considered significant.

\section{RESULTS}

The total number of respondents was 36 (18 males and 18 females). The mean age of all the respondents was 46 years (age range:
- Ladislav Slovacek

- Birgita Slovackova

- Ladislav Jebavy

Zuzana Macingova

\section{ABSTRACT}

CONTEXT AND OBJECTIVE: This study evaluated the effect of selected psychosocial, health and demographic characteristics of quality of life (QOL) among patients treated with autologous hematopoietic stem cell transplantation (HSCT).

DESIGN AND SETTING: This was a retrospective study at Charles University Hospital, Hradec Kralove.

METHODS: The Czech version of the international generic European Quality-of-Life questionnaire (EQ-5D) was applied to evaluate $\mathrm{QOL}$ among patients with acute myeloid leukemia (AML) and malignant Hodgkin's and non-Hodgkin's lymphoma (ML). The total number of respondents was 36: 12 with AML (seven males and five females) and 24 with ML 111 males and 13 females). The mean age of AML respondents was 46 years and the mean age of ML respondents was 44.5 years.

RESULTS: Age, smoking status and education level had statistically significant effects on $\mathrm{QOL}$ among $A M L$ respondents $(p<0.05)$, and age had a statistically significant effect on QOL among $M L$ respondents ( $p<0.05$ ). The overall $Q O L$ among $A M L$ and $M L$ respondents was generally good: the mean EQ-5D score among AML respondents was $71.5 \%$ and among $\mathrm{ML}$ respondents it was $82.7 \%$.

CONCLUSION: The QOL among AML and ML respondents treated with autologous HSCT was good. However, patients more than 50 years old, smokers and patients with lower education levels presented worse QOL. These findings need to be better evaluated in longitudinal studies, using large samples.

KEY WORDS: Quality of life. Patients. Leukemia. Lymphoma. Bone marrow transplantation. 
Table 1. Comparison between mean European Quality-of-Life questionnaire (EQ-5D) score and mean European Quality-of-Life questionnaire (EQ-5D) visual analog scale (VAS) for different age groups, smoking status and education levels among respondents with acute myeloid leukemia (AML) who underwent autologous hematopoietic stem cell transplantation (HSCT) between 2001 and $2003(n=12, p<0.05)$

\begin{tabular}{lcccccc}
\hline & & $\begin{array}{c}\text { Number of } \\
\text { respondents }\end{array}$ & $\begin{array}{c}\text { Mean value for } \\
\text { EQ-5D score (\%) }\end{array}$ & $\begin{array}{c}\text { Standard } \\
\text { deviation }\end{array}$ & $\begin{array}{c}\text { Mean value for } \\
\text { EQ-5D VAS (\%) }\end{array}$ & $\begin{array}{c}\text { Standard } \\
\text { deviation }\end{array}$ \\
\hline \multirow{4}{*}{ Age } & $20-29$ & 1 & 70 & 0 & 60 & 0 \\
range & $30-39$ & 1 & 98 & 0 & 95 & 0 \\
& $40-49$ & 5 & 86.2 & 15.7 & 73.6 & 13.9 \\
\multirow{5}{*}{ Smoking } & $50-59$ & 3 & 60 & 14.5 & 58.3 & 2.4 \\
status & $60-69$ & 2 & 61 & 15 & 56 & 4 \\
\multirow{4}{*}{ Education } & Non-smokers & 6 & 90.7 & 11.4 & 77.2 & 16.4 \\
level & Smokers & 6 & 59.5 & 14.1 & 57.8 & 3.5 \\
& Elementary & 2 & 43 & 4.2 & 53.5 & 2.12 \\
& Apprentice & 3 & 67 & 8.5 & 60 & 0 \\
& Secondary & 3 & 74 & 4.0 & 65 & 8.7 \\
& University & 4 & 98 & 0 & 82 & 17.9 \\
\hline
\end{tabular}

Table 2. Comparison between mean European Quality-of-Life questionnaire (EQ-5D) score and European Quality-of-Life questionnaire (EQ-5D) visual analog scale (VAS) for different age groups among respondents with malignant Hodgkin's and non-Hodgkin's lymphoma (ML) who underwent autologous hematopoietic stem cell transplantation (HSCT) between 2001 and 2003 ( $n=24, p<0.05$ )

\begin{tabular}{ccccccc}
\hline & $\begin{array}{c}\text { Number of } \\
\text { respondents }\end{array}$ & $\begin{array}{c}\text { Mean value for } \\
\text { EQ-5D score (\%) }\end{array}$ & $\begin{array}{c}\text { Standard } \\
\text { deviation }\end{array}$ & $\begin{array}{c}\text { Mean value for } \\
\text { EQ-5D VAS (\%) }\end{array}$ & $\begin{array}{c}\text { Standard } \\
\text { deviation }\end{array}$ \\
\hline \multirow{4}{*}{ Age range } & $20-29$ & 3 & 98 & 0 & 83.3 & 0 \\
& $30-39$ & 6 & 98 & 0 & 86.7 & 0 \\
& $40-49$ & 4 & 98 & 0 & 78.8 & 14.5 \\
& $50-59$ & 7 & 67.3 & 14.5 & 73 & 2.4 \\
& $60-69$ & 4 & 64 & 15 & 65 & 4 \\
\hline
\end{tabular}

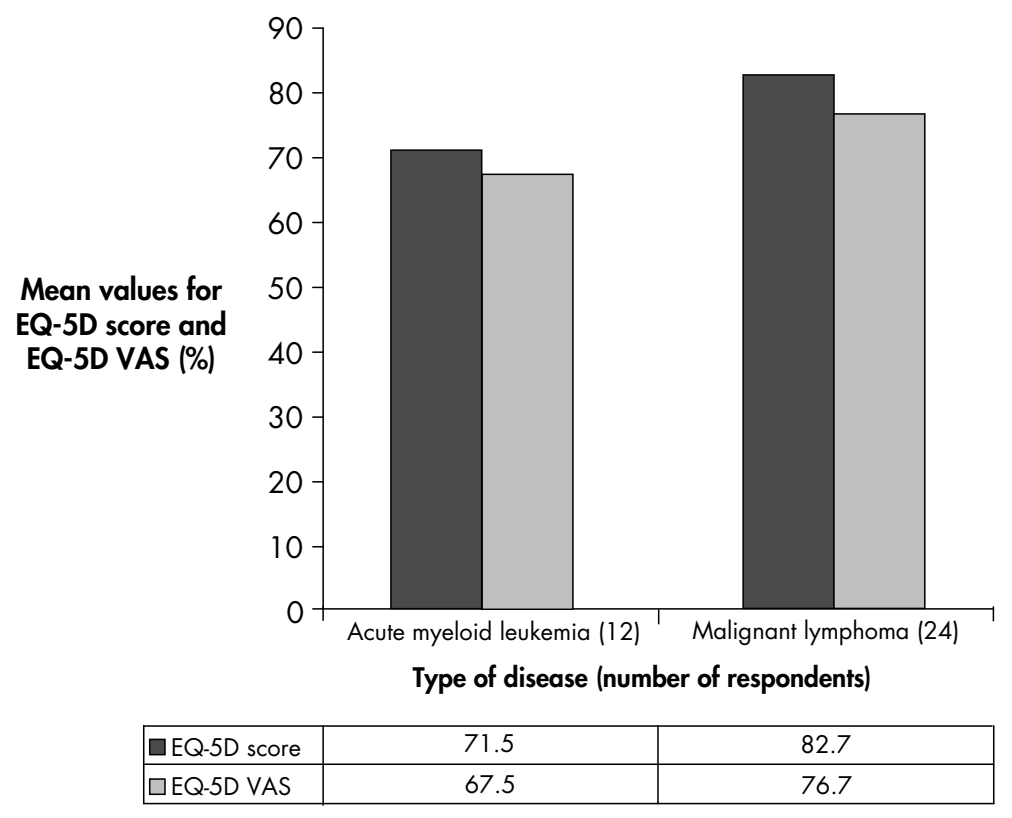

Graph 1. Dependence of European Quality-of-Life questionnaire (EQ-5D) score and European Quality-of-Life questionnaire (EQ-5D) VAS on type of disease among respondents who underwent autologous hematopoietic stem cell transplantation (HSCT) between 2001 and $2003(n=36, p<0.05)$.
18-72). The number of AML respondents was 12 (7 males and 5 females). The mean age of the AML respondents was 46 years (age range: 27-68). The number of ML respondents was 24 (11 males and 13 females). The mean age of the ML respondents was 44.5 years (age range: 18-72). The number of respondents with Hodgkin's lymphoma was nine and with non-Hodgkin's lymphoma was 15.

The overall QOL among AML and ML respondents (Graph 1 ) was generally good. The mean EQ-5D score among AML respondents was $71.5 \%$ and among ML respondents it was $82.7 \%$, while the mean EQ-5D VAS among AML respondents was $67.5 \%$ and among ML respondents it was $76.7 \%$ ).

Age, smoking status and education level had statistically significant effects on QOL among AML respondents $(\mathrm{p}<0.05)$ and age had a statistically significant effect on QOL among ML respondents $(p<0.05)$ (Tables 1 and 2). The results showed that the QOL among AML and ML respondents declined with increasing age. The AML respondents with secondary or university levels of education had higher QOL than did the AML respondents with primary or apprentice levels of education. The AML respondents who were smokers had lower QOL than did the nonsmoking AML respondents.

DISCUSSION

This study showed that selected psychosocial, health and demographics characteristics of AML and ML patients treated with autologous HSCT had significant effects on their QOL. Increasing age and increasing numbers of associated diseases were correlated with lower QOL. This was probably due to overall fatigue, emotional difficulties, lower overall physical fitness and worse quality of sleep.

This explanatory study is the first investigation of QOL among AML and ML patients who had been treated with autologous HSCT in the Czech Republic, and it is one of the few studies carried out in countries of the former Eastern European Block. It has shown some patient characteristics that are associated with better QOL, and thus how they influence post-HSCT QOL. Through this, AML and ML patients who are more than 50 years old, are smokers and have low education levels can be better observed by their doctors, with the aim of developing better strategies to improve their QOL. Further studies will be needed with longitudinal data.

We are also aware that our study may be limited by certain other factors. Firstly, this study deals only with the effect of these se- 
lected psychosocial, health and demographic characteristics on overall QOL. We could also have studied some other characteristics. But we decided to investigate these characteristics because the patients were able and willing to provide this information retrospectively in an anonymous investigation. Secondly, in this study we used the generic European Quality-of-Life questionnaire (EQ-5D) to evaluate QOL among our patients. We decided to use this because our patients were only able and willing to complete this questionnaire. Our patients emphasized that this questionnaire was very intelligible and especially brief. We originally wanted to use the Czech version of the Functional Assessment of Cancer Therapy-General (FACT-G) questionnaire or the European Organization for Research and Treatment of Cancer Quality of Life Core Questionnaire version 3 (EORTC QLQ-C30) questionnaire, but our patients had a negative reaction in relation to completing one of these questionnaires. The patients emphasized that these two questionnaires were very comprehensive and demanded too much of their time.

CONCLUSION

The AML and ML respondents treated with autologous HSCT presented good QOL. Patients who were more than 50 years old, smokers and individuals with lower education levels presented worse QOL. These characteristics need to be better evaluated in longitudinal studies, using large samples.
1. Slovacek L, Slovackova B, Jebavy L. Global quality of life in patients who have undergone the hematopoietic stem cell transplantation: finding from transversal and retrospective study. Exp Oncol. 2005;27(3):238-42.

2. Slovácek L, Slováková B, Jebavy L. Zdravotní a psychosociální aspekty kvality zivota nemocnych s akutní myeloidní leukémií po autologní transplantaci periferních kmenovych bunek. [Healthy and psychosocial aspects of quality of life in patients undergoing autologous progenitor stem cell transplantation]. Cas Lek Cesk. 2006;145(12):949-52; discussion 953-4
3. Ferrans C. Quality of Life Index - Cancer Version. In: King CR, Hinds PS, editors. Quality of life from nursing and patients perspectives. $2^{\text {nd }}$ ed. Boston: Jones and Bartlett Publishers; 2003 p. 451-4.

4. Grant M, Ferrell B, Schmidt GM, Fonbuena P, Niland JC Forman SJ. Measurement of quality of life in bone marrow transplantation survivors. Qual Life Res. 1992;1(6):375-84.

5. EuroQol--a new facility for the measurement of healthrelated quality of life. The EuroQol Group. Health Policy. 1990;16(3):199-208
Acknowledgement: Supported by Research Project from the Ministry of Defense of the Czech Republic, No. OFVZ0000503.

Sources of funding: Supported by Research Project from the Ministry of Defense of the Czech Republic, No. OFVZ0000503

Conflict of interest: None

Date of first submission: January 16, 2007

Last received: November 8, 2007

Accepted: November 9, 2007
AUTHDR INFDRMATIDN

Ladislav Slovacek, MD, PhD. Major in the Department of Field Internal Medicine, Faculty of Military Health Sciences, University of Defence; and Second Department of Clinical Oncology and Radiotherapy, Charles University Hospital, Hradec Kralove, Czech Republic.

Birgita Slovackova, MD, PhD. Department of Psychiatry Charles University Hospital, Hradec Kralove, Czech Republic.

Ladislav Jebavy, MD, PhD. Professor in the Department of Field Internal Medicine, Faculty of Military Health Sciences, University of Defence; and Second Department of Interna Medicine, Charles University Hospital, Hradec Kralove, Czech Republic

Zuzana Macingova, MD. Department of Clinical Oncology and Radiotherapy, Charles University Hospital, Hradec Kralove, Czech Republic.

\section{Address for correspondence:}

Ladislav Slovacek

University of Defence, Faculty of Military Health

Sciences

Department of Field Internal Medicine

Trebesska 1575

50001 Hradec Kralove 1

Czech Republic

Tel: +420-495-834520 - Fax +420-495-832011

E-mail: ladislar slovacek@seznam.cz

Copyright @ 2007 , Associação Paulista de Medicina
RESUMD

Aspectos psicossociais, da saúde e demográficos na qualidade de vida de doentes com leucemia mielóide aguda e linfoma maligno submetidos a transplante autólogo de células tronco do progenitor

CONTEXTO E OBJETIVO: O transplante de células tronco hematopoiéticas (TCTH) é um método a ser utilizado na terapêutica das doenças hemato-oncológicas e tumores sólidos, assim como no tratamento de doenças não-malignas. O TCTH tem influência na evolução da doença e na qualidade de vida do doente, assim como outros métodos curativos.

TIPO ESTUDO E LOCAL: Este estudo é retrospectivo. Foi desenvolvido no Departamento Clínico de Hematologia do 2ㅇ Departamento de Medicina Interna do Hospital da Universidade de Charles em Hradec Kralove, República Checa.

MÉTODOS: Amostra de 36 adultos sujeitos ao tratamento com transplante autólogo de células tronco do progenitor, sendo 12 com leucemia mielóide aguda: sete homens e cinco mulheres, e 24 com linfoma maligno: 11 homens e 13 mulheres. Foi utilizada a versão checa do questionário internacional de qualidade de vida européia versão $E Q-5 D$.

RESULTADOS: Houve associação estastiticamente significante entre qualidade de vida e idade, fumantes, pacientes com baixo nível educacional em ambos os sujeitos com leucemia mielóide aguda $(p<0.05)$. Houve associacão estatisticamente significante entre qualidade de vida e idade em ambos os sujeitos com linfoma maligno $(p<0.05)$

CONCLUSÃO: A qualidade de vida dos pacientes com linfoma maligno e leucemia mielóide aguda, submetidos a transplante autólogo do progenitor, mantém-se preservada na maioria dos pacientes. Pacientes com idade acima de 50 anos, baixo nível educacional e fumantes têm pior qualidade de vida. Estes fatores devem ser melhor avaliados em estudos longitudinais e com amostras maiores.

PALAVRAS-CHAVE: Qualidade de vida. Pacientes. Leucemia. Linfoma. Transplante de medula óssea. 